\title{
Effects of stimulation of frontal cortex on neuronal activity in association and sensory areas of the cortex'
}

LEWIS A. BETTINGER, HERMAN BIRCH, PHILIP M. GROVES, KATHLEEN S. MAYERS, and RICHARD F. THOMPSON, Department of Psychobiology, University of California, Irvine, Califormia' 92664

Electrical stimulation of frontal cortex of anesthetized cat suppressed or abolished responses of polysensory cells in association cortex to subsequent peripheral stimuli. The same frontal shock train enhanced subsequent evoked activity of approximately half the cells studied in primary auditory and visual areas of the cortex.

Attention, defined as behavioral orienting, results in marked depression in evoked cortical activity recorded from nonspecific "association" areas in the cat (Thompson \& Shaw, 1965). In humans, attention to a sudden stimulus is accompanied by increases in the amplitude of the later components of the primary sensory evoked responses recorded from the scalp (Spong, Haider, \& Lindsley, 1964; Groves \& Eason, 1968). Both types of changes in these gross measures of evoked cortical activity may occur following electrical stimulation of the frontal association response fields in cat (Thompson, Denney, \& Smith, 1966). This report indicates that single cell responses to peripheral stimuli are suppressed in posterior association cortex and enhanced in primary auditory and visual areas of the cortex following frontal stimulation.

\section{METHOD}

Single unit activity was recorded in area PMSA (posterior middle suprasylvian association field) and in primary auditory (AI) and visual (VI) areas of the cortex of cats anesthetized with chloralose $(70 \mathrm{mg} / \mathrm{kg})$, utilizing standard tungsten microelectrodes. Animals were routinely immobilized with Flaxedil and artificially respirated. Stimulation of the frontal cortex was accomplished by delivering $.25 \mathrm{msec}$ pulses at a rate of $200 / \mathrm{sec}$ for $100 \mathrm{msec}$ through a pair of silver wire electrodes $2 \mathrm{~mm}$ apart placed on the cortex $3 \mathrm{~mm}$ anterior to the cruciate sulcus. Peripheral stimuli were light flash, free field click, and shock to the ipsilateral forepaw, presented at various intervals $(10-100 \mathrm{msec})$ following the cortical shock train. Interstimulus intervals were always greater than $3 \mathrm{sec}$.

\section{RESULTS}

All cells studied in posterior association cortex (PMSA) responded to the three modalities of peripheral stimulation in the absence of frontal shock. In most instances the shack train to frontal cortex did not itself fire units, although increased background unit activity was often seen following frontal stimulation. On the other hand, the cellular responses in PMSA to the peripheral stimuli were invariably diminished by prior frontal stimulation over the intervals studied.

Data from over 20 polysensory cells in PMSA suggest that the inhibition of unit firing can occur as a reduction in the number of spikes evoked in a neuron by a given peripheral stimulus, a reduction in the probability that the cell will discharge at all to a peripheral stimulus, or both. Activity of a cell illustrating total suppression of response is shown in Fig. 1. In general, the number of discharges in a given burst would decrease when the peripheral stimulus was preceded by low voltage frontal shock and would be completely inhibited by higher shock intensities.

Cells in primary auditory (AI) and visual (VI) cortical areas showed either no change ( $33 \%$ of cells in AI and $44 \%$ of cells in VI) or an increased number of spike discharges (67\% of cells in AI and $56 \%$ in VI) to a given stimulus following frontal stimulation. The primary cortical cells were never observed to discharge to frontal shock alone. This enhanced firing could be potentiated by increasing the intensity of the frontal shock. An example of increased firing of a cell in visual cortex following frontal stimulation is shown in Fig. 2.
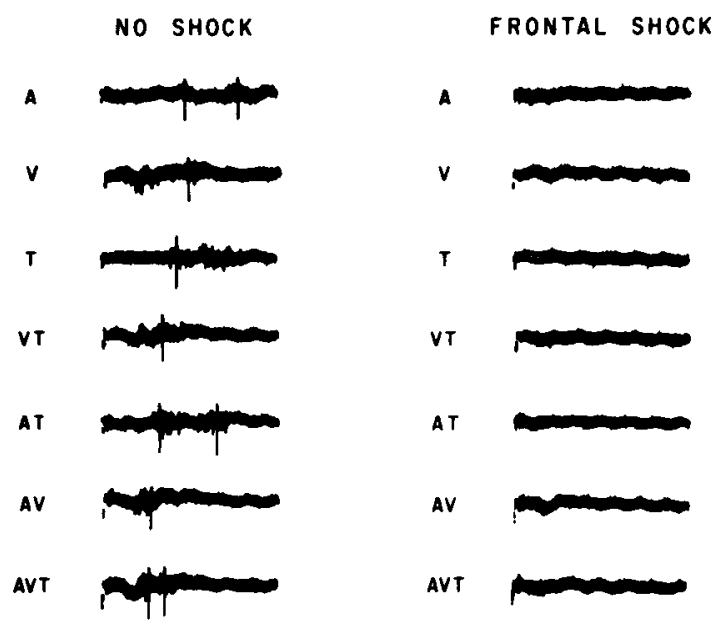

$25 \mathrm{msec}$

Fig. 1. Responses of cell in suprasylvian gyrus of cat to auditory, visual and tactile stimuli alone and in combinations with and without shock trail to frontal cortex prior to stimulation.

\section{DISCUSSION}

The results of this experiment and others (Spinelli \& Pribram, 1967; Skinner \& Lindsley, 1967) suggest that activity in the frontal cortex influences both nonspecific and specific input to the cerebral cortex. Studies by Krauthamer \& Albe-Fessard (1965) and Buser (1966) indicate that stimulation of the caudate nucleus may inhibit nonspecific input at thalamic levels. It is possible that stimulation of frontal cortex suppressed evoked activity in association cortex via activation of the caudate nucleus. Adkins, Morse, \& Towe (1966) have shown that direct electrical stimulation of the pyramidal tract may increase the receptive field and discharge probability of cortical neurons in primary somatic sensory cortex by facilitating cells in brain stem relay nuclei. Since our frontal stimulus probably activated the pyramidal tract, it is possible that the facilitation of cells in auditory and visual areas of the cortex was so mediated.

While the functional significance of these systems is yet to be demonstrated in the waking animal, it is clear from the present investigation that stimulation of the frontal cortex in acute preparations may mimic the regional increases and decreases in cortical excitability which have been found to occur when an organism "attends" to a sensory stimulus.

\section{NO SHOCK}

.2

.3

.5

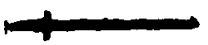

FRONTAL SHOCK

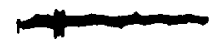

.2

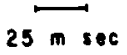

Fig. 2. Responses of cell in primary visual cortex of cat to flash with and without prior frontal shock train. Numbers indicate probability of the illustrated response. 


\section{REFERENCES}

ADKINS, R. J., MORSE, R. W., \& TOWE, A. L. Control of somatosensory input by cerebral cortex. Science, 1966, 153, 1020-1022.

BUSER, P. Subcortical controls of pyramidal activity. In D. P. Purpura and M. D. Yahr (Eds.), The thalamus. New York: Columbia University Press, 1966.

GROVES, P. M., \& EASON, R. G. Effects of attention and activation on the visual evoked cortical potential and reaction time. Psychophysiology, 1968 , in press.

KRAUTHAMER, G., \& ALBE-FESSARD, D. Inhibition of nonspecific sensory activities following striopallidal and capsular stimulation. Journal of Neurophysiology, 1965, 28, 100-124.

SKINNER, J., \& LINDSLEY, D. Electrophysiological and behavior effects of blockade of the nonspecific thalamo-cortical system. Brain Research, 1967, 6, 95-118.
SPINELLI, D., \& PRIBRAM, K. Changes in visual recovery function and unit activity produced by frontal cortex stimulation. Electroencephalography \& Clinical Neurophysiology, 1967, 22, 143-149.

SPONG, P., HAIDER, M., \& LINDSLEY, D. Selective attentiveness and cortical evoked responses to visual and auditory stimuli. Science, 1965, $148,395.397$.

THOMPSON, R., \& SHAW, J. Behavioral correlates of evoked activity recorded from association areas of the cerebral cortex. Journal of Comparative \& Physiological Psychology, 1965, 60, 329-339.

NOTE

1. Supported in part by Grant NB 02161 from the National Institutes of Health and Research Scientist Award MH06650 from the National Institute of Mental Health. 